\title{
Synergism between plant extract and antimicrobial drugs used on Staphylococcus aureus diseases
}

\author{
Joyce Elaine Cristina Betoni, Rebeca Passarelli Mantovani, Lidiane Nunes Barbosa, \\ Luiz Claudio Di Stasi*, Ary Fernandes Junior/ ${ }^{+}$
}

\author{
Departamento de Microbiologia e Imunologia * Departamento de Farmacologia, Instituto de Biociências, \\ Universidade Estadual Paulista Julio de Mesquita Filho, 18618-000 Botucatu, SP, Brasil
}

\begin{abstract}
Searches for substances with antimicrobial activity are frequent, and medicinal plants have been considered interesting by some researchers since they are frequently used in popular medicine as remedies for many infectious diseases. The aim of this study was to verify the synergism between 13 antimicrobial drugs and 8 plant extracts "guaco" (Mikania glomerata), guava (Psidium guajava), clove (Syzygium aromaticum), garlic (Allium sativum), lemongrass (Cymbopogon citratus), ginger (Zingiber officinale), "carqueja" (Baccharis trimera), and mint (Mentha piperita) - against Staphylococcus aureus strains, and for this purpose, the disk method was the antimicrobial susceptibility test performed. Petri dishes were prepared with or without dilution of plant extracts at sub-inhibitory concentrations in Mueller-Hinton Agar (MHA), and the inhibitory zones were recorded in millimeters. In vitro anti-Staphylococcus aureus activities of the extracts were confirmed, and synergism was verified for all the extracts; clove, guava, and lemongrass presented the highest synergism rate with antimicrobial drugs, while ginger and garlic showed limited synergistic capacity.
\end{abstract}

Key words: medicinal plants - Staphylococcus aureus - antimicrobial drugs - synergism - Kirby \& Bauer method

In a constant attempt to improve their quality of life, men have used plants as source of food, shelter, clothing, medicine, cosmetics, and for seeking relief from hardship of life. Some plants are known as medicinal because they contain active substances that cause certain reactions, from relenting to the cure of diseases, on the human organism (Silva Junior et al. 1994). Knowledge on medicinal plants sometimes means the only therapeutic resource of some communities and ethnic groups (Di Stasi 1996); and their use, especially in South America, contributes significantly to primary health care (Holetz et al. 2002). Infectious diseases still represent an important cause of morbidity and mortality among humans, especially in developing countries. Even though pharmaceutical industries have produced a number of new antimicrobial drugs in the last years, resistance to these drugs by microorganisms has increased. In general, bacteria have the genetic ability to transmit and acquire resistance to drugs used as therapeutic agents (Nascimento et al. 2000).

In vitro studies on plants used in traditional medicine have been carried out in the field of microbiology, especially on pathogenic bacterial growth; and some of these studies were about the antimicrobial activity of Mikania glomerata Spreng ("guaco") (Boyayan 2002, Holetz et al. 2002), Psidium guajava L (guava) (Gnan \& Demello 1999, Jaiarj et al. 1999, Nascimento et al. 2000, Ahmad \& Beg 2001, Abdelrahim et al. 2002, Holetz et al. 2002, Voravuthikunchai et al. 2004, Qadan et al. 2005), Syzygium

\footnotetext{
Financial support: Fapesp

+Corresponding author: ary@ibb.unesp.br

Received 21 January 2006

Accepted 8 May 2006
}

aromaticum (L) Merrill \& Perry (clove) (Lopez et al. 2005), Allium sativum L (garlic) (Ankri \& Mirelman 1999, Ahmad \& Beg 2000, Srinivasan et al. 2001, Benkeblia 2004), Zingiber officinale Roscoe (ginger) (Silva Junior et al. 1994, Konning et al. 2004), Cymbopogon citratus (DC) Stapf (lemongrass) (Cimanga et al. 2002, Di Stasi \& HirumaLima 2002), Mentha piperita L (mint) (Silva Junior et al. 1994, Tassou et al. 2000), and Baccharis trimera (Less.) DC ("carqueja") (Avancini et al. 2000).

A recent paper on medicinal plants and antimicrobial activity whose objective was to analyze past, present, and future of medicinal plants to suggested as fundamental the research on plant extract mechanism of action, interactions with antibiotics or with other medicinal plants, and extracts pharmacokinetic profile (Ríos \& Recio 2005). Research on synergism is very limited and few studies have been reported (Nascimento et al. 2000, Aburjai et al. 2001, Aqil et al. 2005). Thus, in our research, we evaluated in vitro synergism between extracts of $M$. glomerata, $P$. guajava, S. aromaticum, A. sativum, C. citratus, $Z$. officinale, B. trimera, and M. piperita and antimicrobial drugs utilized against $S$. aureus strains by using the Kirby \& Bauer method.

\section{MATERIALS AND METHODS}

Plant samples - M. glomerata, P. guajava, B. trimera, $M$. piperita, and $C$. citratus samples were collected in 2004 from an experimental field of the School of Agronomical Sciences, Unesp, Botucatu, São Paulo, Brazil, and the voucher specimens were deposited at the Herbarium of the Department of Botany, Institute of Biosciences, Unesp. Their leaves were dried at $40^{\circ} \mathrm{C}$ and triturated in a mechanical mill. A. sativum, S. aromaticum, and $Z$. officinale samples were obtained from the local commerce in the same year and were used in natura for the extracts preparation. 
Preparation of plant extracts - Plant material, dried (M. glomerata, P. guajava, B. trimera, M. piperita, C. citratus) or not (A. sativum, S. aromaticum, Z. officinale) was ground, extracted with $70 \%$ methanol and filtered after $48 \mathrm{~h}$. The plant residue was re-extracted with addition of $70 \%$ methanol, and after $24 \mathrm{~h}$ it was filtered again. Combined filtrates were concentrated on a rotary evaporator at $45^{\circ} \mathrm{C}$ for methanol elimination, and the extracts were kept in sterile bottles under refrigerated conditions until use. The extracts' dry weight was obtained by the solvent evaporation and used to determine concentration in $\mathrm{mg} / \mathrm{ml}$.

Bacterial strains - Thirty-two $S$. aureus strains were isolated from clinical specimens of newborns admitted to the Neonatal Unit of the Hospital of the School of Medicine, Botucatu, SP, Brazil. Strains were isolated in sheep blood agar and, after identification (Koneman et al. 2005), they were stored in brain heart infusion (BHI) plus agar.

Antimicrobial tests - Before the synergism assays between the plant extracts and the antimicrobial drugs were evaluated, the minimal inhibitory concentration (MIC) of the extracts was determined for 32 S. aureus strains by diluting the extracts in Mueller Hinton agar (MHA) media (NCCLS 2004a,b). Petri dishes, controls and with different concentrations of plant extracts $(\mathrm{mg} / \mathrm{ml})$, were inoculated with $S$. aureus strains $\left(10^{4} \mathrm{CFU}\right)$ using a Steer's replicator and were incubated at $37^{\circ} \mathrm{C} / 24 \mathrm{~h}$. The concentration that inhibited visible growth of each strain (MIC) was recorded, and the MIC 90\% was calculated. Onefourth the MIC $90 \%$ was considered as the sub-inhibitory concentration of the plant extracts in the synergism assays (Mahon \& Manuselis 1995), which were carried out on 15 S. aureus strains, including the ATCC 13565 strain by the disk diffusion method (Kirby \& Bauer method) (NCCLS 2004) on MHA media. Thirteen drugs were evaluated: penicillin (PEN; $10 \mathrm{IU}$ ), oxacillin (OXA; $1 \mu \mathrm{g}$ ), vancomycin (VAN; $30 \mu \mathrm{g}$ ), ampicillin (AMP; $10 \mu \mathrm{g}$ ), cephalothin (CFL; $30 \mu \mathrm{g}$ ), cefoxitin (CFO; $30 \mu \mathrm{g}$ ), chloramphenicol (CLO; $30 \mu \mathrm{g}$ ), gentamicin (GEN; $10 \mu \mathrm{g}$ ), netilmicin (NET; $30 \mu \mathrm{g}$ ), tetracycline (TET; $30 \mu \mathrm{g}$ ), erythromycin (ERI; 15 $\mu \mathrm{g}$ ), cotrimoxazole (SUT; $25 \mu \mathrm{g}$ ), and ofloxacin (OFX; 5 $\mu \mathrm{g})$. Two antibiogram sets were performed in duplicate for each $S$. aureus strain in control plates, with plain MHA, and in plates containing MHA plus one-fourth the MIC $90 \%$ of the respective extracts. The diameters $(\mathrm{mm})$ of the each inhibitory zone were recorded after incubation at $37^{\circ} \mathrm{C} / 18 \mathrm{~h}$.

Statistical analysis - Results from the synergism assays were subjected to the Wilcoxon nonparametric test to compare the values $(\mathrm{mm})$ of the inhibitory zones obtained by the disk diffusion method (Minitab Statistical Software version 13.32). Results were considered significant when $\mathrm{p}<0.05$.

\section{RESULTS AND DISCUSSION}

Characteristics, MIC 90\% (mg/ml) against 32 S. aureus strains, and one-fourth the MIC $90 \%$ values obtained in the synergism assays for the plants and their respective extracts are presented in Table I. Anti-S. aureus activity was verified for all the plants. S. aromaticum showed the highest activity, followed by $P$. guajava; the lowest activity was recorded for lemongrass. The MIC $90 \%$ range was $0.36 \mathrm{mg} / \mathrm{ml}$ for clove and $17.84 \mathrm{mg} / \mathrm{ml}$ for C. citratus and it is not surprising the differences in the antimicrobial activity of plants tested, due to phytochemical properties and differences among species. Although the antimicrobial activities of $C$. citratus, B. trimera, and Z. afficinale, have not been relatively high, synergism assays were carried out for them and the synergism rate of $C$. citratus was as high as that of S. aromaticum (Table II).

Antimicrobial mechanisms of the drugs used here were variable and the protein synthesis inhibitors were those that presented strongest synergistic effect (5.2 extracts/ drug) together with folic acid (4 extracts/drug) and bacterial cell wall synthesis (3.8 extracts/drug) inhibitors. Inhibitors of the nucleic acid synthesis (2 extracts/drug) showed weak synergism with plant extracts. Among the protein synthesis inhibitors, tetracycline showed synergism with all the extracts, followed by chloramphenicol and netilmicim. The synergistic capacity was promising for the extracts of some plants such as $S$. aromaticum, $C$. citrates, and P. guajava, which presented synergism with 11,11 , and 9 drugs, respectively; while garlic and ginger showed synergism with only 3 and 2 drugs, respectively.

The high synergism rate of protein synthesis inhibitors, although an important data, shows the need for more studies concerning the molecular basis of these interactions. Similar results with synergism of protein synthesis

TABLE I

Characteristics, minimal inhibitory concentration 90\% (MIC 90\%) values, and sub-inhibitory one-fourth the MIC $90 \%$ values obtained in the synergism assays for the plants and their extracts used

\begin{tabular}{|c|c|c|c|c|c|c|}
\hline $\begin{array}{l}\text { Scientific } \\
\text { name }\end{array}$ & $\begin{array}{l}\text { Common } \\
\text { name }\end{array}$ & $\begin{array}{l}\text { Part of the } \\
\text { plant used }\end{array}$ & Efficacy $(\%)$ & $\begin{array}{c}\text { Extracts' dry } \\
\text { Weight (mg/ml) }\end{array}$ & $\begin{array}{c}\text { MIC 90\% } \\
(\mathrm{mg} / \mathrm{ml})\end{array}$ & $\begin{array}{c}1 / 4 \mathrm{MIC} 90 \% \\
(\mathrm{mg} / \mathrm{ml})\end{array}$ \\
\hline Allium sativum & Garlic & Bulbs & - & 94.12 & 5.05 & 1.26 \\
\hline Baccharis trimera & “Carqueja” & Leaves & 55.07 & 52.75 & 7.23 & 1.80 \\
\hline Cymbopogon citratus & Lemongrass & Leaves & 25.62 & 63.87 & 17.84 & 4.46 \\
\hline Mikania glomerata & "Guaco" & Leaves & 28.48 & 59.62 & 3.80 & 0.95 \\
\hline Psidium guajava & Guava & Leaves & 47.68 & 131.75 & 0.52 & 0.13 \\
\hline Syzygium aromaticum & Clove & Flower buds & - & 58.75 & 0.36 & 0.09 \\
\hline Zingiber officinale & Ginger & Rhizomes & - & 11.75 & 3.56 & 0.89 \\
\hline Mentha piperita & Mint & Leaves & 20.83 & 11.0 & 2.20 & 0.55 \\
\hline
\end{tabular}

(-): for non-dried plants the efficacy was considered $100 \%$. 
TABLE II

Synergism rate between antimicrobial drugs and plant extracts against 15 Staphylococcus aureus strains by the Kirby and Bauer method

\begin{tabular}{|c|c|c|c|c|c|c|c|c|c|c|c|}
\hline Drug target & Drug & $\begin{array}{l}\text { Psidium } \\
\text { guajava }\end{array}$ & $\begin{array}{l}\text { Syzygium } \\
\text { aromaticum }\end{array}$ & $\begin{array}{l}\text { Allium } \\
\text { sativum }\end{array}$ & $\begin{array}{l}\text { Mikania } \\
\text { glomerata }\end{array}$ & $\begin{array}{l}\text { Baccharis } \\
\text { trimera }\end{array}$ & $\begin{array}{l}\text { Zingiber } \\
\text { officinale }\end{array}$ & $\begin{array}{l}\text { Mentha } \\
\text { piperita }\end{array}$ & $\begin{array}{l}\text { ymbopogon } \\
\text { citratus }\end{array}$ & $\begin{array}{r}\text { Syne } \\
\text { (extı }\end{array}$ & gism rate \\
\hline \multirow[t]{5}{*}{ Protein synthesis } & TET & $\mathrm{x}$ & $\mathrm{x}$ & $\mathrm{x}$ & $\mathrm{x}$ & $\mathrm{x}$ & $\mathrm{x}$ & $\mathrm{x}$ & $\mathrm{x}$ & 8 & \multirow[t]{5}{*}{5.2} \\
\hline & CLO & $\mathrm{x}$ & $\mathrm{x}$ & - & $\mathrm{x}$ & $\mathrm{x}$ & - & $\mathrm{x}$ & $\mathrm{x}$ & 6 & \\
\hline & NET & - & - & - & $\mathrm{x}$ & $\mathrm{x}$ & $\mathrm{x}$ & $\mathrm{x}$ & $\mathrm{x}$ & 5 & \\
\hline & ERI & $\mathrm{x}$ & $\mathrm{x}$ & - & - & $\mathrm{x}$ & - & $\mathrm{x}$ & - & 4 & \\
\hline & GEN & - & - & $\mathrm{x}$ & $\mathrm{x}$ & - & - & $\mathrm{x}$ & - & 3 & \\
\hline \multirow[t]{6}{*}{ cell wall synthesis } & VAN & $\mathrm{x}$ & $\mathrm{x}$ & - & $\mathrm{x}$ & $\mathrm{x}$ & - & - & $\mathrm{x}$ & 5 & \multirow[t]{6}{*}{3.8} \\
\hline & PEN & - & $\mathrm{x}$ & - & $\mathrm{x}$ & $\mathrm{x}$ & - & - & $\mathrm{x}$ & 4 & \\
\hline & OXA & $\mathrm{x}$ & $\mathrm{x}$ & - & - & - & - & $\mathrm{x}$ & $\mathrm{x}$ & 4 & \\
\hline & CFL & $\mathrm{x}$ & $\mathrm{x}$ & - & $\mathrm{x}$ & - & - & - & $\mathrm{x}$ & 4 & \\
\hline & AMP & $\mathrm{x}$ & $\mathrm{x}$ & - & - & - & - & - & $\mathrm{x}$ & 3 & \\
\hline & $\mathrm{CFO}$ & $\mathrm{x}$ & $\mathrm{x}$ & - & - & - & - & - & $\mathrm{x}$ & 3 & \\
\hline Folic acid & SUT & $\mathrm{x}$ & $\mathrm{x}$ & $\mathrm{x}$ & - & - & - & - & $\mathrm{x}$ & 4 & 4 \\
\hline Nucleic acids & OFX & - & $\mathrm{x}$ & - & - & - & - & - & $\mathrm{x}$ & 2 & 2 \\
\hline Total & 13 & 9 & 11 & 3 & 6 & 6 & 2 & 6 & 11 & & \\
\hline
\end{tabular}

$\mathrm{x}$ : synergism when $\mathrm{p} \leq 0.05$; (-) no synergism; TET: tetracycline; CLO: chloramphenicol; NET: netilmicin; ERI: erythromycin; GEN: gentamicin; VAN: vancomycin; PEN:penicillin; OXA: oxacillin; CFL: cephalothin; AMP: ampicillin; CFO: cefoxitin; SUT: cotrimoxazole; OFX: ofloxacin.

inhibitors and propolis ethanolic extract of Apis mellifera by E-test and disk diffusion methods were reported by Fernandes Junior et al. (2005).

The synergism recorded here to plant extracts with weak action on S. aureus growth, such as lemongrass, is an important data since it showed a synergism profile similar to that of the clove extract, considered the most efficient $S$. aureus growth inhibitor in this study. Thus, the researchers should investigate the synergistic capacity of plant extracts or other natural products, independent of the antimicrobial activity they have. Therefore, the results of the present study seem to be promising and may enhance the natural products uses, showing the potential of these plants in the treatment of infectious diseases caused by S. aureus. Future studies on the chemical characteristics of extracts and active components should be carried out for each plant and antimicrobial property, since only crude extracts and their dry weight have been used in MIC determination (expressed in $\mathrm{mg} / \mathrm{ml}$ ) and synergism assays.

In the present study, the antimicrobial activity of plant extracts on S. aureus strains were confirmed and synergism was possible with all the antimicrobial drugs tested. Tetracycline presented synergism with all the extracts; and the $C$. citratus extract, although with the lowest antimicrobial activity, presented a synergism profile similar to that of S. aromaticum, whose extract showed a relatively high inhibitory capacity on $S$. aureus growth. The possible activities of substances found in plant extracts on ribosome structure and bacterial enzymes inhibition appear to be related with synergism profile between plant extracts and inhibitors of protein synthesis, however, the understanding of synergism mechanism is fundamental to development of pharmacological agents to treat diseases by $S$. aureus using medicinal plants.

\section{ACKNOWLEDGMENTS}

To Dr Lin Chau Ming (FCA/Unesp/Botucatu) for providing the plant specimens supply; Dr Maria de Lourdes Ribeiro de Souza da Cunha for S. aureus strains and Dr Lidia Raquel de Carvalho (IBB/UNESP/Botucatu) for the statistical analysis.

\section{REFERENCES}

Abdelrahim SI, Almagboul AZ, Omerb MEA, Elegamib A 2002. Antimicrobial activity of Psidium guajava L. Fitoterapia 73: 713-715.

Aburjal T, Darwish RM, Al-Khalil S, Mahgzah A, Al-Abbdi A 2001. Screening of antibiotic resistant inhibitors from local plant materials against two different strains of Pseudomonas aeruginosa. J Ethnopharmacol 76: 39-44.

Ahmad I, Beg AZ 2001. Antimicrobial and phytochemical studies on 45 Indian medicinal plants against multi-drug resistant human pathogens. J Ethnopharmacol 74: 113-123.

Ankri S, Mirelman D 1999. Antimicrobial properties of allicin from garlic. Microb Infect 2: 125-129.

Aqil F, Khan MSA, Owais M, Ahmad I 2005. Effect of certain bioactive plant extracts on clinical isolates of $\beta$-lactamase producing methicilin resistant Staphylococcus aureus. J Basic Microbiol 45: 106-114.

Avancini CAM, Wiest JM, Mundstock E 2000. Bacteriostatic and bactericidal activity of the Baccaris trimera (Less.) D.C. - Compositae decocto, as disinfectant or antisseptic. Arq Bras Med Vet Zootec 52: 230-234.

Benkeblia N 2004. Antimicrobial activity of essential oil extracts of various onions (Allium cepa) and garlic (Allium sativum). Lebensm.-Wiss u Technol 37: 263-268.

Boyayan M 2002. O guaco, planta nativa da mata Atlântica, tem mais propriedades terapêuticas do que se supunha. Rev Pesquisa FAPESP 74: 48-49.

Cheeptham N, Towers GHN 2002. Light-mediated activities of 
some Thai medicinal plant teas. Fitoterapia 73: 651-662.

Cimanga K, Kambu K, Tona L, Apers S, de Bruyne T, Hermans N, Totté J, Pieters L, Vlietinck AJ 2002. Correlation between chemical composition and antibacterial activity of essential oils of some aromatic medicinal plants growing in the Democratic Republic of Congo. J Ethnopharmacol 79: 213-220.

Di Stasi LC 1996. Arte, ciência e magia. In LC Di Stasi, CA Hiruma-Lima (eds), Plantas Medicinais: Arte e Ciência, Unesp, São Paulo, p. 15-21.

Di Stasi LC, Hiruma-Lima CA 2002. Plantas Medicinais na Amazônia e na Mata Atlântica, 2nd ed., Unesp, São Paulo, $604 \mathrm{pp}$.

Fernandes Junior A, Balestrin ECC, Betoni JEC, Orsi RO, Cunha MLR, Montelli AC 2005. Propolis: anti-Staphylococcus aureus activity and synergism with antimicrobial drugs. Mem Inst Oswaldo Cruz, 100: 563-566.

Gnan SO, Demello MT 1999. Inhibition of Staphylococcus aureus by aqueous goiaba extracts. $J$ Ethnopharmacol 68: 103-108.

Holetz FB, Pessini GL, Sanches NR, Cortez DAG, Nakamura CV, Dias Filho BP 2002. Screening of some plants used in the Brazilian folk medicine for the treatment of infectious diseases. Mem Inst Oswaldo Cruz 97: 1027-1031.

Jairj P, Khoohaswan P, Wongkrajan Y, Peungvicha P, Suriywong P, Sumal Saraya ML, Ruangsomboon O 1999. Anticough and antimicrobial activities of Psidium guajava Linn. leaf extract. J Ethnopharmacol 67: 203-212.

Koneman EW, Allen SD, Janda NM, Schreckemberger PC, Winn Jr WC 2005. Diagnósticdo Microbiológico: Texto e Atlas Colorido, 5th ed., Medis, Rio de Janeiro, 1465 pp.

Konning GH, Ayare C, Ennison B 2004. Antimicrobial activity of some medicinal plants from Ghana. Fitoterapia 75: 6567.

López P, Sánches C, Batlle R, Nerín C 2005. Solid-and vapor- phase antimicrobial activities of six essencial oils: susceptibility of selected foodborne bacterial and fungal strains. $J$ Agric Food Chem 53: 6939-6946.

Mahon CR, Manuselis Jr G 1995. Textbook of Diagnostic Microbiology, WB, Saunders, Philadelphia, $1134 \mathrm{pp}$.

Nascimento GGF, Locatelli J, Freitas PC, Silva GL 2000. Antibacterial activity of plant extracts and phytochemicals on antibiotic-resistant bacteria. Braz J Microbiol 31: 247-256.

NCCLS-National Committee for Clinical Laboratory Standards 2004a. Method for dilution antimicrobial susceptibility tests for bacterial that grow aerobically, 7th ed., Approved Standard M7.A6. Wayne, Pennsylvania.

NCCLS-National Committee for Clinical Laboratory Standards 2004a. Performance standards for antimicrobial disk susceptibility tests, 7th ed., Approved Standard M2-A8, Wayne, Pennsylvania.

Qadan F, Thewaini AJ, Ali DA, Afifi R, Elkhawad A, Matalka KZ 2005. The antimicrobial activities of Psidium guajava and Juglans regia leaf extracts to acne-developing organisms. Am J Chin Med 33: 197-205.

Ríos JL, Recio MC 2005. Medicinal plants and antimicrobial activity. J Ethnopharmacol 100: 80-84.

Silva Junior AA, Vizotto VJ, Giorgi E, Macedo SG, Marques LF 1994. Plantas medicinais, caracterização e cultivo. EPAGRI. Bol Técnico Florianópolis 68: 1-71.

Srinivasan D, Nathan S, Suresh T, Perumalsamy PL 2001. Antimicrobial activity of certain Indian medicinal plants used in folkloric medicine. J Ethnopharmacol 74: 217-220.

Tassou CC, Koutsoumanis K, Nychas GJE 2000. Inhibition of Salmonella enteridis and Staphyloccus aureus on nutrient broth by mint essential oil. Food Res Internat 48: 273-280.

Voravuthikuchai S, Lortheeranuwat A, Jeeju W, Sririrak T, Phongpaichit S, Supawita T 2004. Effective medicinal plants against entherohaemorragic Escherichia coli O157:H7. J Ethnopharmacol 94: 49-54. 